\title{
Comparing Biocompatibility of Nanocrystalline Titanium and Titanium-Oxide with Microcrystalline Titanium
}

\author{
Raheleh Miralami \\ University of Nebraska Medical Center, raheleh.miralami@unmc.edu \\ Laura Koepsell \\ University of Nebraska Medical Center \\ Thyagaseely Sheela Premaraj \\ University of Nebraska Medical Center, sheelapremaraj@unmc.edu \\ Bongok Kim \\ University of Nebraska - Lincoln \\ Geoffrey M. Thiele \\ University of Nebraska Medical Center, gthiele@unmc.edu
}

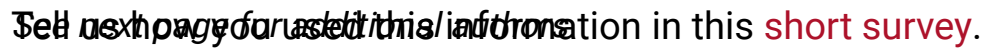

Follow this and additional works at: https://digitalcommons.unmc.edu/com_ortho_pres

Part of the Orthopedics Commons

\section{Recommended Citation \\ Miralami, Raheleh; Koepsell, Laura; Premaraj, Thyagaseely Sheela; Kim, Bongok; Thiele, Geoffrey M.; Sharp, J. Graham; Garvin, Kevin L.; and Namavar, Fereydoon, "Comparing Biocompatibility of Nanocrystalline Titanium and Titanium-Oxide with Microcrystalline Titanium" (2013). Posters and Presentations: Orthopaedic Surgery \& Rehab. 2. \\ https://digitalcommons.unmc.edu/com_ortho_pres/2}

This Conference Proceeding is brought to you for free and open access by the Orthopaedic Surgery \& Rehab at DigitalCommons@UNMC. It has been accepted for inclusion in Posters and Presentations: Orthopaedic Surgery \& Rehab by an authorized administrator of DigitalCommons@UNMC. For more information, please contact digitalcommons@unmc.edu. 


\section{Authors}

Raheleh Miralami, Laura Koepsell, Thyagaseely Sheela Premaraj, Bongok Kim, Geoffrey M. Thiele, J. Graham Sharp, Kevin L. Garvin, and Fereydoon Namavar 

Titanium-Oxide with Microcrystalline Titanium

R. Miralami ${ }^{1}$, L. Koepsell ${ }^{1}$, T. Premaraj' ${ }^{2}$, B. Kim ${ }^{3}$, G.M. Thiele ${ }^{4}$, J.G. Sharp ${ }^{5}$, K.L. Garvin ${ }^{1}$, F. Namavar ${ }^{1}$

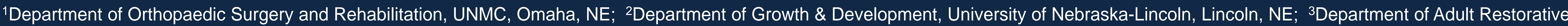

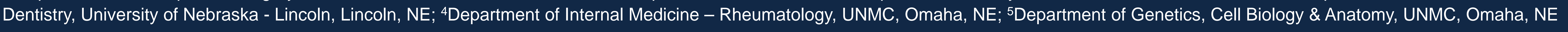
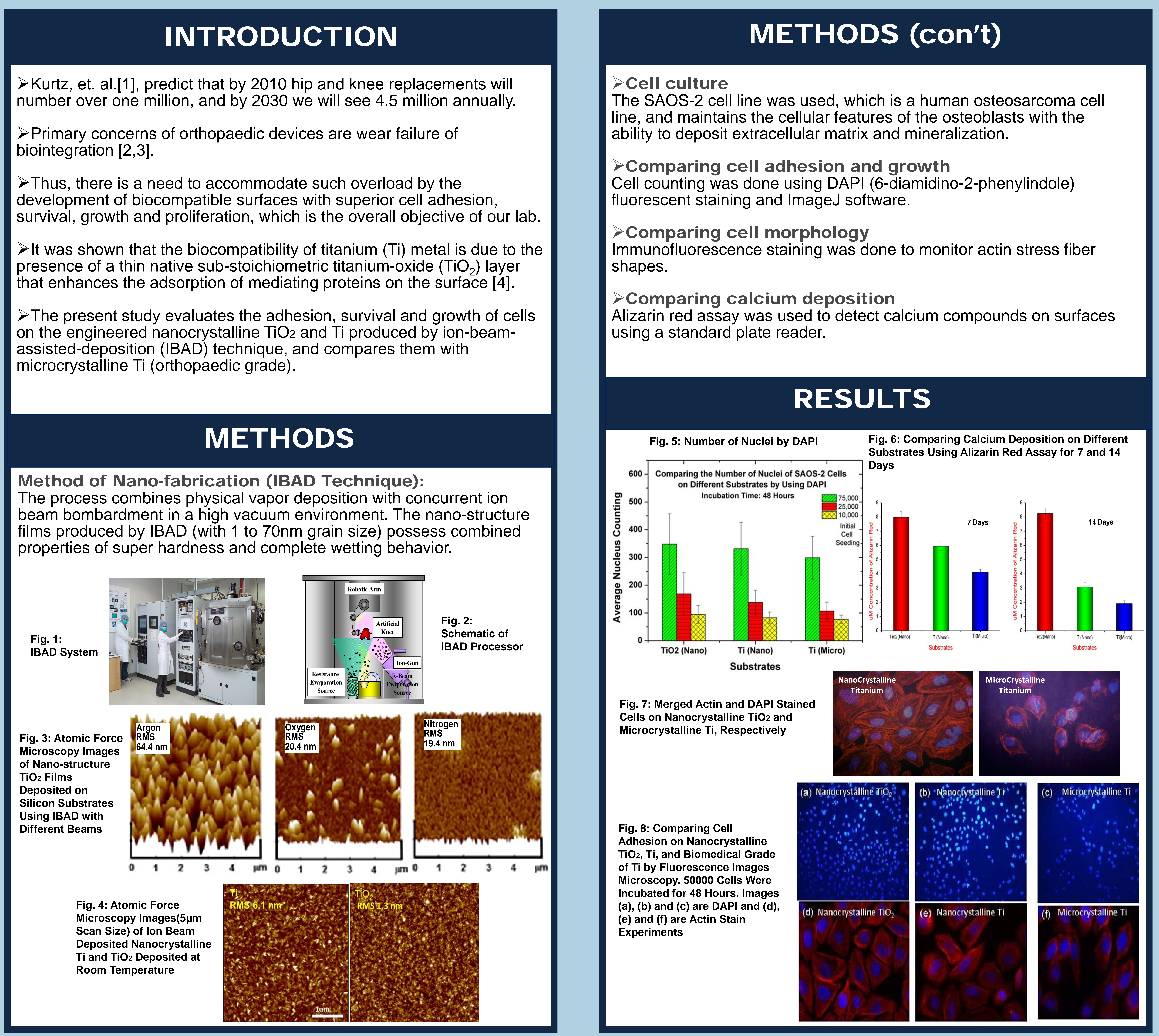

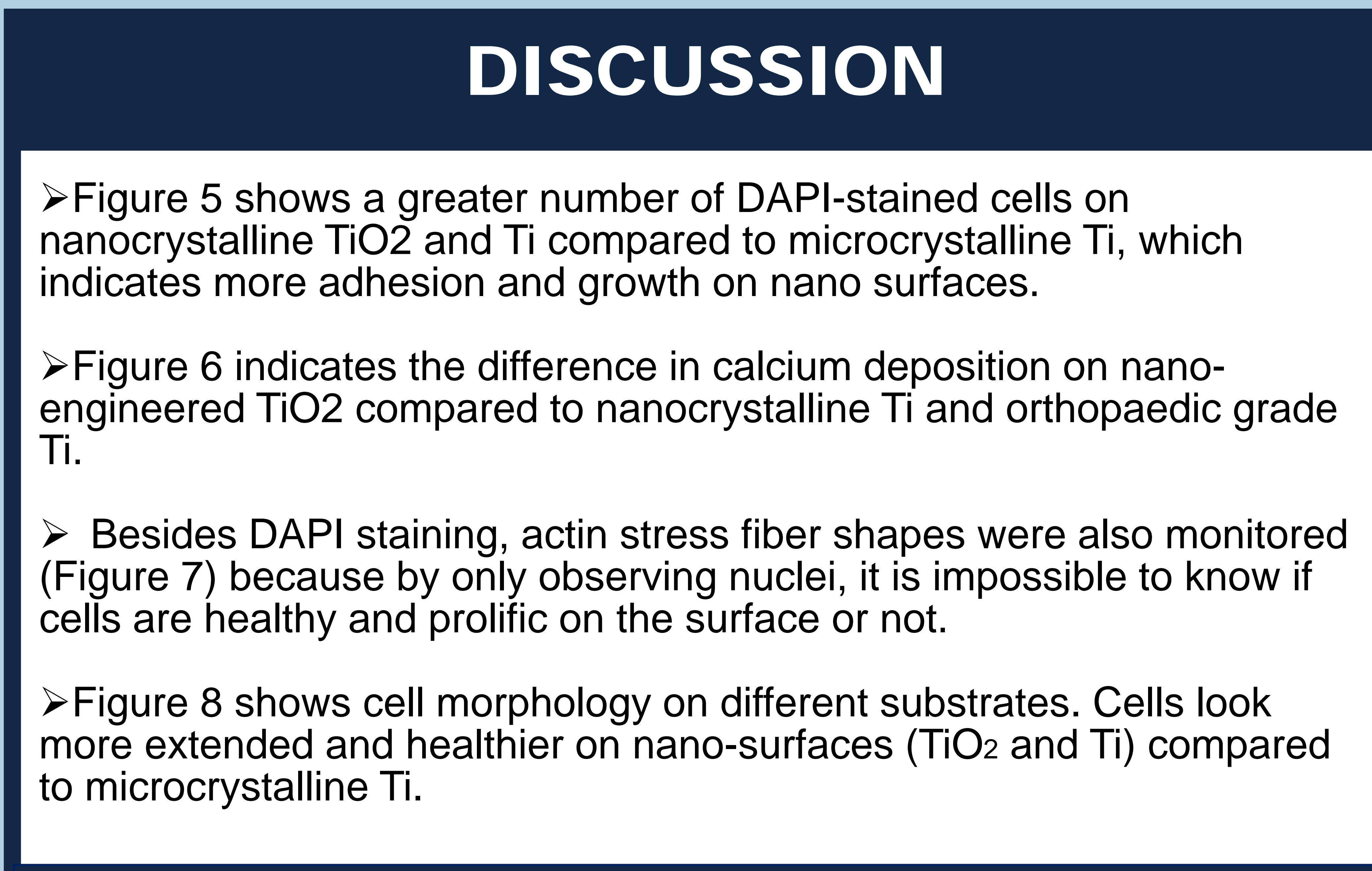

\section{CONCLUSION}

> Nanocrystalline surfaces $\left(\mathrm{TiO}_{2}\right.$ and $\left.\mathrm{Ti}\right)$ are superior in supporting to the nano-crystal film characteristics that affect the wettability and mechanical properties of the coatings.

Nano-engineered $\mathrm{TiO}_{2}$ is superior to both nano and biomedical grade TI eccause of the improved quality of the oxide layer by employing an IBAD technique.

Osteoblastic cells deposit calcium in order to support bone construction The cells cultured on the nano surfaces showed more calcium dep (brighter red color in alizarin red staining), which implies a higher degree can be expected from the engineered nano structured surfaces.

\section{ACKNOWLEDGMENT} This work was supported by department of energy, material science
smart coating (DE-SC0005318).

\section{REFERENCES}

1. S. Kurtz, et. al, American Academy of Orthopaedic Surgeons, L.G. Harris, et. al. Injury. Int. J. Care Injured. 37, S3-S14, 2006

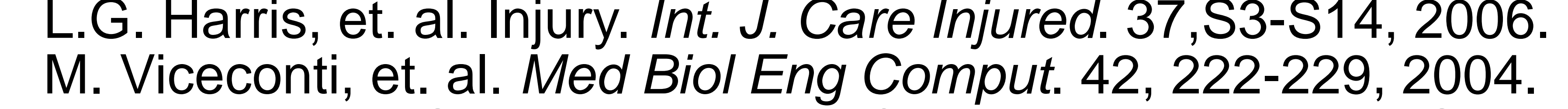
M. Namavar, R. Sabirianov; et. al. Orthopaedic Research Society
San Francisco, Feb 2012 . 